\title{
Pengaruh pertumbuhan ekonomi terhadap kemiskinan Kabupaten Tanjung Jabung Timur
}

\author{
Risang Dwi Anggoro*; Syaparuddin; Nurhayani
}

Prodi Ekonomi Pembangunan Fak. Ekonomi dan Bisnis Universitas Jambi

*E-mail korespondensi: Aangneimo@gmail.com

\begin{abstract}
This study aims to determine the economic development of poverty in East Tanjung Jabung Regency. The data is used in this study is secondary data in the form of time series data and economic growth rate in East Tanjung Jabung Regency. The method of analysis is used in this study is a simple regression. The results of this study indicated that significant capital expenditures to the GDP of the food crops sub-sector and the revenue of regency/city in Jambi Province have no significant effect. Likewise, with strong changes in the number of poor people, the percentage of poor, poverty indices, and poverty severity indices have no significant effect.
\end{abstract}

Keywords: Economic growth, Poverty.

\begin{abstract}
Abstrak
Penelitian ini bertujuan untuk mengetahui pengaruh pertumbuhan ekonomi terhadap kemiskinan di Kabupaten Tanjung Jabung Timur. Data yang dikumpulkan dalam penelitian ini adalah data sekunder yang berupa data time series laju pertumbuhan ekonomi dan kemiskinan di Kabupaten Tanjung Jabung Timur. Metode analisis yang digunakan dalam penelitian ini adalah regresi sederhana. Hasil penelitian ini menunjukkan bahwa belanja modal berpengaruh signifikan terhadap PDRB subsektor tanaman pangan dan perkebunan kabupaten/kota di Provinsi Jambi pertumbuhan ekonomi tidak memiliki pengaruh yang signifikan terhadap garis kemiskinan. Begitupun dengan pengaruh pertumbuhan ekonomi terhadap jumlah penduduk miskin, persentase penduduk miskin, indeks kedalaman kemiskinan, dan indeks keparahan kemiskinan yang menunjukkan tidak adanya pengaruh yang signifikan.
\end{abstract}

Kata kunci: Pertumbuhan ekonomi, Kemiskinan.

\section{PENDAHULUAN}

Pembangunan merupakan proses yang berkesinambungan dengan tujuan akhir untuk meningkatkan kesejahteraan masyarakat. Oleh karena itu, strategi pembangunan haruslah dapat memacu pertumbuhan ekonomi serta meningkatkan kualitas sumber daya manusia. Berdasarkan tujuan dan strategi pembangunan tersebut, maka pelaksanaan pembangunan harus diarahkan pada hal-hal yang dapat meningkatkan kesejahteraan masyarakat. Pembangunan pada umumnya difokuskan pada pembangunan ekonomi melalui usaha peningkatan pertumbuhan ekonomi. Pembangunan diidentikkan dengan upaya peningkatan pendapatan perkapita atau populer disebut strategi pertumbuhan ekonomi. Diharapkan dengan meningkatnya pendapatan perkapita masalah-masalah yang dihadapi seperti pengangguran, kemiskinan, dan ketimpangan distribusi pendapatan dapat terpecahkan.

Tujuan dasar dan paling essensial dari pembangunan tidak lain adalah mengangkat kehidupan manusia yang berada pada lapisan paling bawah atau penduduk miskin, kepada tingkatan yang lebih baik dari waktu ke waktu. Pembangunan yang dilaksanakan di berbagai sektor kehidupan juga pada dasarnya adalah untuk 
menyejahterakan seluruh lapisan masyarakat yang utamanya adalah masyarakat lapisan terbawah atau masyarakat miskin. Kemiskinan menyebabkan seseorang atau sekelompok orang tidak mampu memenuhi hak-hak dasarnya seperti tidak terpenuhinya kebutuhan pangan, kesehatan, pendidikan, pekerjaan, perumahan, air bersih, pertanahan, sumber daya alam dan lingkungan hidup.

Semakin tinggi jumlah dan persentase penduduk miskin di suatu daerah akan menjadi tinggi beban pembangunan. Oleh sebab itu pembangunan dikatakan berhasil bila jumlah dan persentase penduduk miskinnya turun atau bahkan tidak ada. Untuk itu pemerintah dengan berbagai program berupaya menanggulangi kemiskinan, namun pengentasan kemiskinan belum mencapai hasil maksimal dan belum sesuai dengan harapan. Persentase kemiskinan memang turun dari tahun ke tahun namun jumlah penduduk miskin di Indonesia pada tahun 2009 masih cukup besar yaitu 32,53 juta atau sekitar 14,15 persen dari total penduduk.

Adanya kemiskinan merupakan faktor penduduk yang kehidupannya di bawah garis kemiskinan akibat dari ketidakmerataan dalam distribusi pembangunan, yang juga disebabkan oleh faktor penduduknya yang mengalami kemiskinan secara alamiah maupun kultural yang ditunjukkan oleh situasi lingkaran ketidakberdayaan bersumber dari rendahnya tingkat pendidikan, pendapatan, kesehatan dan gizi, produktivitas, penguasaan modal, keterampilan dan tekonologi serta hambatan infrastruktur maupun etnis sosial beragam lainnya. esensi utama dari masalah kemiskinan adalah masalah aksesibilitas. Aksesibilitas berarti kemampuan seseorang atau sekelompok orang dalam masyarakat untuk mendapatkan sesuatu yang merupakan kebutuhan dasarnya dan seharusnya menjadi haknya sebagai manusia dan sebagai warga negara.

Pertumbuhan ekonomi yang cukup tinggi di Provinsi Jambi tidak terlepas dari pembangunan ekonomi di kabupaten/kota yang ada di Provinsi Jambi. Penerapan otonomi daerah yang menjadikan wilayah kabupaten/kota sebagai titik sentral dalam proses pembangunan. Oleh karena itu, proses pembangunan yang terjadi di wilayah kabupaten/kota inilah yang menjadi tumpuan pembangunan di Provinsi Jambi.

Kabupaten Tanjung Jabung Timur merupakan wilayah kabupaten dengan tingkat kemiskinan tertinggi di Provinsi Jambi. Kemiskinan merupakan masalah utama pembangunan di Kabupaten Tanjung Jabung Timur, yang ditunjukkan dengan besarnya jumlah penduduk miskin. Angka kemiskinan di Kabupaten Tanjung Jabung Timur pada tahun 2015 mencapai nilai 14,17\% sedangkan angka kemiskinan di Provinsi Jambi secara keseluruhan sebesar 8,86\%. Berdasarkan data Badan Pusat Statistik Provinsi Jambi (2015) menunjukkan bahwa dalam lima tahun terakhir tingkat kemiskinan di Kabupaten Tanjung Jabung Timur justru mengalami peningkatan. Pada tahun 2011 tingkat kemiskinan di Kabupaten Tanjung jabung Timur sebesar 11,60\%, meningkat menjadi $12,50 \%$ pada tahun 2012 , kemudian menjadi $12,87 \%$ di tahun $2013,13,55 \%$ di tahun 2014 dan terakhir pada tahun 2015 menjadi 14,17\%. Kondisi ini perlu mendapat perhatian serius dari Pemerintrah Kabupaten Tanjung Jabung Timur sehingga dengan segera mampu mengentaskan kemiskinan dan meningkatkan kesejahteraan masyarakat sesuai dengan tujuan pembangunan.

Kemiskinan terutama banyak dijumpai pada petani dan nelayan yang merupakan 69,34\% dari angkatan kerja. Kemiskinan pada petani terutama dijumpai pada petani pangan, karena hanya menghasilkan panen satu kali dalam satu tahun dengan produksi rata-rata 3,45 ton per hektar. Kelompok lain adalah masyarakat nelayan yang acap terperangkap pada kondisi, ketidakmampuan menggerakkan dan memanfaatkan sumber daya laut dan wilayah pesisir untuk kehidupan mereka. Kemiskinan dapat terjadi karena kekurangan modal, rendahnya produktivitas, dan lemahnya penguasaan teknologi.

\section{METODE}

Data yang digunakan dalam penelitian ini adalah data sekunder, yaitu jenis data yang diperoleh dan digali melalui hasil pengolahan dari pihak kedua dari hasil penelitian 
lapangannya, baik berupa data kualitatif atau pun kualitatif. Data sekunder umumnya berupa bukti, catatan atau laporan historis yang telah tersusun dalam arsip (data dokumenter) yang dipublikasikan dan yang tidak dipublikasikan. Data penelitian berupa data statistik pertumbuhan ekonomi dan kemiskinan Kabupaten Tanjung Jabung Timur periode tahun 2004-2015.

Data yang dikumpulkan dalam penelitian ini adalah data sekunder yang berupa data time series berupa data laju pertumbuhan ekonomi kabupaten/kota di Provinsi Jambi tahun 2004-2015 dan kemiskinan di Provinsi Jambi menurut kabupaten/kota tahun 20022015. Data bersumber dari situs Badan Pusat Statistik Provinsi Jambi.

Analisis regresi sederhana digunakan untuk menjawab tujuan penelitian kedua yaitu mengetahui pengaruh pertumbuhan ekonomi terhadap kemiskinan Kabupaten Tanjung Jabung Timur. Kemiskinan dalam penelitian ini diukur berdasarkan indikator pengukuran kemiskinan yang digunakan oleh BPS menggunakan lima indikator yaitu: garis kemiskinan, jumlah penduduk miskin, persentase penduduk miskin, indeks keparahan kemiskinan, dan indeks kedalaman kemiskinan. Pengaruh pertumbuhan ekonomi terhadap kemiskinan dapat dirumuskan sebagai berikut:

\begin{tabular}{|c|c|}
\hline GK & $=\beta_{0}+\beta_{1} \mathrm{PE}+e \mathrm{i}$ \\
\hline JPM & $=\beta_{0}+\beta_{1} \mathrm{P} e+e \mathrm{i} \ldots \ldots \ldots .$. \\
\hline PPM & $=\beta_{0}+\beta_{1} \mathrm{P} e+e \mathrm{i} \ldots \ldots \ldots . .$. \\
\hline $\mathrm{KdK}$ & 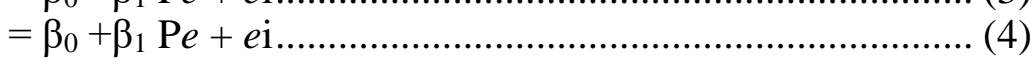 \\
\hline
\end{tabular}

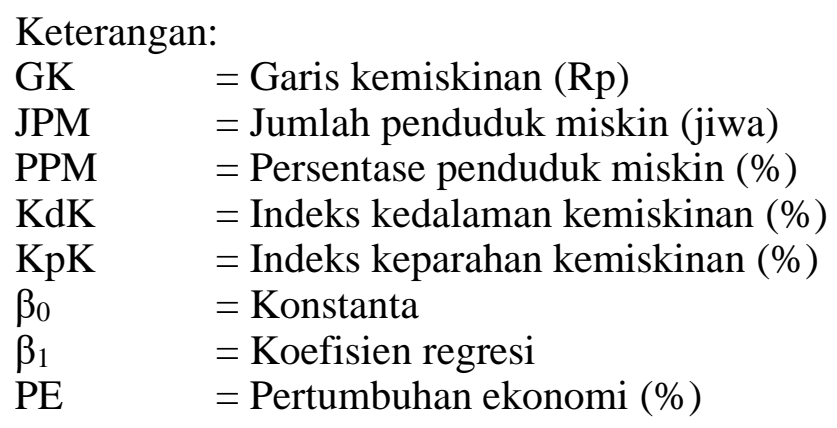

\section{HASIL DAN PEMBAHASAN}

\section{Perkembangan pertumbuhan ekonomi di Kabupaten Tanjung Jabung Timur tahun 2004-2015}

Pertumbuhan ekonomi menunjukkan bagaimana hasil pembangunan yang terlaksana di Kabupaten Tanjung Jabung Timur yang diukur dengan perkembangan pendapatan domestik Kabupaten Tanjung Jabung Timur pada setiap tahunnnya menggunakan data PDRB atas dasar harga konstan. Perkembangan pertumbuhan ekonomi di Kabupaten Tanjung Jabung Timur selama tahun 2004-2015 digambarkan dalam Tabel 1.

Berdasarkan tabel 1 terlihat bahwa selama tahun 2004-2015 cenderung fluktuatif. Pertumbuhan ekonomi tertinggi terjadi di tahun 2012 dengan nilai pertumbuhan sebesar $7,44 \%$, sedangkan pertumbuhan ekonomi terendah terjadi di tahun 2015 yang hanya sebesar $1,87 \%$. Terjadinya penurunan yang cukup signifikan dikarenakan masih belum stabilnya perkembangan harga kelapa sawit dan karet yang menjadi penopang utama perekonomian di Kabupaten Tanjung Jabung Timur, sedangkan sektor lainnya belum cukup mampu mendukung perkembangan ekonomi di Kabupaten Tanjung Jabung Timur. 
Pertumbuhan ekonomi mengalami peningkatan pada tahun 2005, 2006, 2008, 2010, 2011, 2012, dan 2014, sedangkan di tahun 2007, 2009, dan 2015 justru mengalami penurunan

Tabel 1: Perkembangan pertumbuhan ekonomi di Kabupaten Tanjung Jabung Timur tahun 2004-2015

\begin{tabular}{rc}
\hline Tahun & Pertumbuhan ekonomi $(\boldsymbol{\%})$ \\
\hline 2004 & 3,19 \\
2005 & 3,67 \\
2006 & 5,88 \\
2007 & 4,71 \\
2008 & 5,71 \\
2009 & 5,00 \\
2010 & 5,78 \\
2011 & 6,83 \\
2012 & 7,44 \\
2013 & 4,09 \\
2014 & 5,92 \\
2015 & 1,87 \\
\hline Total & $\mathbf{5 , 0 1}$ \\
\hline
\end{tabular}

Sumber: Data diolah, 2017

\section{Perkembangan kemiskinan di Kabupaten Tanjung Jabung Timur tahun 2004-2015 Garis kemiskinan}

Garis kemiskinan merupakan standar penilaian kemiskinan secara absolut yaitu standar kehidupan minimum yang dibutuhkan untuk memenuhi kebutuhaan dasar yang diperlukan, baik makanan maupun non makanan. Berdasarkan tabel 2 di atas menunjukkan bahwa selama tahun 2004-2015, garis kemiskinan di Kabupaten Tanjung Jabung Timur cenderung mengalami peningkatan. Penurunan hanya terjadi di tahun 2007 dari Rp.169.019 di tahun sebelumnya menjadi Rp.158.909 atau menurun sebesar 5,98\%. Peningkatan tertinggi terjadi di tahun 2006 yang meningtkat sebesar 26,54\% dari Rp.133.573 di tahun 2005 menjadi Rp.169.909 pada tahun 2006.Perkembangan garis kemiskinan di Kabupaten Tanjung Jabung Timur tahun 2004-2015 dapat dilihat pada tabel berikut ini:

Tabel 2 : Perkembangan garis kemiskinan di Kabupaten Tanjung Jabung Timur Tahun $2004-2015$

\begin{tabular}{rc}
\hline Tahun & Garis kemiskinan (Rp) \\
\hline 2004 & 126.428 \\
2005 & 133.573 \\
2006 & 169.019 \\
2007 & 158.909 \\
2008 & 191.981 \\
2009 & 213.056 \\
2010 & 244.160 \\
2011 & 252.716 \\
2012 & 266.685 \\
2013 & 283.415 \\
2014 & 293.057 \\
2015 & 201.563 \\
\hline Total & $\mathbf{2 1 9 . 5 4 6 , 8 3}$ \\
\hline
\end{tabular}

Sumber: Data diolah, 2017 


\section{Jumlah penduduk miskin}

Jumlah penduduk miskin menunjukkan seberapa banyak penduduk di Kabupaten Tanjung Jabung Timur yang berada di bawah garis kemiskinan. Gambaran mengenai jumlah penduduk miskin di Kabupaten Tanjung Jabung Timur dapat dilihat pada tabel berikut ini:

Tabel 3 : Perkembangan jumlah penduduk miskin di Kabupaten Tanjung Jabung

Timur tahun 2004-2015

\begin{tabular}{rc}
\hline Tahun & Perkembangan (\%) \\
2004 & - \\
2005 & 18.30 \\
2006 & 3,96 \\
2007 & $-2,08$ \\
2008 & 1,77 \\
2009 & $-8,33$ \\
2010 & $-3,79$ \\
2011 & 3,94 \\
2012 & $-0,76$ \\
2013 & 8,05 \\
2014 & 1,70 \\
2015 & 4,83 \\
\hline Total & $\mathbf{2 , 5 1}$ \\
\hline
\end{tabular}

Sumber: Data diolah, 2017

Berdasarkan tabel 3 menunjukkan bahwa seiring dengan peningkatan garis kemiskinan selama tahun 2004-2015, jumlah penduduk miskin di Kabupaten Tanjung Jabung Timur juga cenderung mengalami peningkatan. Penurunan jumlah penduduk miskin terjadi di tahun 2007, 2009, dan 2012, sedangkan pada tahun-tahun lainnya jumlah penduduk miskin di Kabupaten Tanjung Jabung Timur mengalami peningkatan. Peningkatan tertinggi terjadi di tahun 2005 yang meningkat sebesar 18,30\% dari tahun sebelumnya. Sementara itu, penurunan jumlah penduduk miskin tertinggi terjadi di tahun 2009 yang menurun sebesar $8,33 \%$ dibanding jumlah penduduk miskin tahun sebelumnya.

\section{Persentase penduduk miskin}

Persentase penduduk miskin menggambarkan perbandingan jumlah penduduk miskin dengan jumlah seluruh penduduk di Kabupaten Tanjung Jabung Timur. Gambaran mengenai perkembangan persentase penduduk miskin di Kabupaten Tanjung Jabung Timur dapat dilihat pada Tabel 4.

Berdasarkan tabel 4 di atas menunjukkan bahwa dilihat dari perbandingan jumlah penduduk miskin dengan jumlah penduduk di Kabupaten Tanjung Jabung Timur secara keseluruhan, persentase penduduk miskin juga cenderung meningkat. Penurunan hanya terjadi di tahun 2007, 2009, dan 2011, sedangkan di tahun-tahun lainnya mengalami peningkatan. Seperti halnya perkembangan jumlah penduduk miskin, persentase penduduk miskin mengalami peningkatan tertinggi di tahun 2005 yang meningkat dari 11, 61\% pada tahun 2004 menjadi 13,44\% pada tahun 2005. Sementara itu persentase penduduk miskin mengalami penurunan tertinggi di tahun 2009 yang mengalami penurunan dari $13,49 \%$ menjadi $12,21 \%$. 
Tabel 4. Perkembangan persentase penduduk miskin di Kabupaten Tanjung Jabung Timur tahun 2004-2015

\begin{tabular}{rc}
\hline Tahun & Persentase penduduk miskin (\%) \\
\hline 2004 & 11,61 \\
2005 & 13,44 \\
2006 & 13,97 \\
2007 & 13,44 \\
2008 & 13,49 \\
2009 & 12,21 \\
2010 & 12,40 \\
2011 & 11,60 \\
2012 & 12,50 \\
2013 & 12,87 \\
2014 & 13,55 \\
2015 & 14,17 \\
\hline Total & $\mathbf{1 2 , 9 4}$ \\
\hline
\end{tabular}

Sumber: Data diolah, 2017

\section{Indeks kedalaman kemiskinan}

Indeks kedalaman kemiskinan (Poverty gap index-P1), merupakan ukuran ratarata kesenjangan pengeluaran masing-masing penduduk miskin terhadap garis kemiskinan. Semakin tinggi nilai indeks, semakin jauh rata-rata pengeluaran pesuduk dari garis kemiskinan. Berdasarkan tabel 5 menunjukkan bahwa indeks kedalaman kemiskinan di Kabupaten Tanjung Jabung Timur cenderung menurun. Tahun 2004 indeks kedalaman kemiskinan sebesar 2,45, sedangkan di tahun 2015 sebesar 1,98. Hal ini berarti selama 12 tahun, dari tahun 2004 - 2015, ukuran kesenjangan rata-rata penduduk miskin dengan garis kemiskinan semakin tipis yang menunjukkan bahwa pendapatan perkapita penduduk semakin merata di Kabupaten Tanjung Jabung Timur.

Tabel 5. Perkembangan indeks kedalaman kemiskinan di Kabupaten Tanjung Jabung Timur tahun 2004-2015

\begin{tabular}{rc}
\hline Tahun & Kedalaman kemiskinan (\%) \\
\hline 2004 & 2,45 \\
2005 & 2,66 \\
2006 & 2,36 \\
2007 & 1,96 \\
2008 & 2,27 \\
2009 & 1,76 \\
2010 & 1,22 \\
2011 & 1,84 \\
2012 & 1,66 \\
2013 & 1,67 \\
2014 & 1,92 \\
2015 & 1,98 \\
\hline Total & $\mathbf{1 , 9 8}$ \\
\hline
\end{tabular}

Sumber: Data diolah, 2017

Peningkatan indeks kedalaman kemiskinan terjadi pada tahun 2005, 2008, 2011, 2013, 2014, dan 2015, sedangkan tahun 2006, 2007, 2009, 2010, dan 2012 menurun. Indeks kedalaman kemiskinan tertinggi terjadi di tahun 2005 sebesar 2,66\%, sedangkan terendah terjadi di tahun 2011 dengan nilai sebesar 1,22\%. Peningkatan indeks kedalaman kemiskinan yang tertinggi terjadi pada tahun 2011 yang meningkat dari 1,22\% menjadi $1,84 \%$, sedangkan penurunan terbesar terjadi di tahun 2010 yang mengalami penurunan 
dari 1,76\% menjadi 1,22\%. Gambaran mengenai indeks kedalaman kemiskinan di Kabupaten Tanjung Jabung Timur dapat dilihat pada Tabel 5.

\section{Indeks keparahan kemiskinan}

Indeks keparahan kemiskinan (Proverty severity index-P2) memberikan gambaran mengenai penyebaran pengeluaran di antara penduduk miskin. Semakin tinggi nilai indeks, semakin tinggi ketimpangan pengeluaran di antara penduduk miskin. Gambaran mengenai indeks keparahan kemiskinan di Kabupaten Tanjung Jabung Timur dapat dilihat pada tabel berikut ini:

Tabel 6. Perkembangan indeks keparahan kemiskinan di Kabupaten Tanjung Jabung Timur tahun 2004-2015

\begin{tabular}{rc}
\hline Tahun & Keparahan kemiskinan (\%) \\
\hline 2004 & 0,61 \\
2005 & 0,82 \\
2006 & 0,60 \\
2007 & 0,49 \\
2008 & 0,54 \\
2009 & 0,40 \\
2010 & 0,23 \\
2011 & 0,49 \\
2012 & 0,36 \\
2013 & 0,36 \\
2014 & 0,44 \\
2015 & 0,45 \\
\hline Total & $\mathbf{0 , 4 8}$ \\
\hline
\end{tabular}

Sumber: Data diolah, 2017

Berdasarkan Tabel 6 menunjukkan bahwa indeks keparahan kemiskinan di Kabupaten Tanjung Jabung Timur cenderung fluktuatif. Indeks keparahan kemiskinan mengalami peningkatan pada tahun 2005, 2008, 2011, 2014, dan 2015, sedangkan pada tahun 2006, 2007, 2009, 2010, dan 2012 mengalami penurunan. Indeks keparahan kemiskinan mengalami peningkatan yang tertinggi pada tahun 2011 yang meningkat dari $0,23 \%$ pada tahun 2010 menjadi $0,49 \%$ pada tahun 2011 . Penurunan terbesar terjadi pada tahun 2010 yang menurun dari 0,40\% pada tahun 2009 menjadi 0,23\% di tahun 2010 .

\section{Pengaruh pertumbuhan ekonomi terhadap kemiskinan di Kabupaten Tanjung Jabung Timur tahun 2004-2015}

Hasil analisis pengaruh pertumbuhan ekonomi terhadap garis kemiskinan di Kabupaten Tanjung Jabung Timur Tahun 2004-2015 dapat dilihat pada tabel berikut:

Tabel 7. Hasil analisis pengaruh pertumbuhan ekonomi terhadap garis kemiskinan di Kabupaten Tanjung Jabung Timur tahun 2004-2015

\begin{tabular}{lrrc}
\hline Variabel & Koefisien & thitung & Sig \\
\hline Constant & 186363,298 & 2,896 & 0,016 \\
PE & 6626,767 & 0,539 & 0,602 \\
$\mathrm{t}_{\text {tabel }}=1,812$ & & & \\
\hline
\end{tabular}

Sumber: Data diolah, 2017

Berdasarkan hasil analisis Tabel 7 maka dapat dirumuskan persamaan sebagai berikut:

$\mathrm{GK}=186363,298+6626,767 \mathrm{PE}$ 
Dari persamaan regresi dan tabel di atas dapat dijelaskan sebagai berikut: Dari tabel 7 diketahui nilai thitung bernilai positif sebesar 0,539 sedangkan $t_{\text {tabel }}$ pada $\mathrm{dk}=$ $\mathrm{n}-1=11$, yaitu sebesar 2,201. Dengan demikian $\mathrm{t}_{\text {hitung }}<\mathrm{t}_{\text {tabel }}$, begitupun signifikansi sebesar 0,602 yang lebih besar dari taraf signifikansi $(\alpha)=0,05$. Hal ini berarti bahwa $\mathrm{H}_{\mathrm{o}}$ diterima $\mathrm{H}_{\mathrm{a}}$ ditolak. Dengan demikian pertumbuhan ekonomi tidak memiliki pengaruh yang signifikan terhadap garis kemiskinan.

\section{Pengaruh pertumbuhan ekonomi terhadap jumlah penduduk miskin di Kabupaten Tanjung Jabung Timur tahun 2004-2015}

Hasil analisis pengaruh pertumbuhan ekonomi terhadap jumlah penduduk miskin di Kabupaten Tanjung Jabung Timur tahun 2004-2015 dapat dilihat pada tabel berikut:

Tabel 8. Hasil analisis pengaruh pertumbuhan ekonomi terhadap jumlah penduduk miskin di Kabupaten Tanjung Jabung Timur tahun 2004-2015

\begin{tabular}{lccc}
\hline \multicolumn{1}{c}{ Variabel } & Koefisien & thitung & Sig \\
\hline Constant & 28494,382 & 14,916 & 0,000 \\
PE & $-215,553$ & $-0,591$ & 0,568 \\
$\mathrm{t}_{\text {tabel }}=1,812$ & & & \\
\hline
\end{tabular}

Sumber: Data diolah, 2017

Berdasarkan hasil analisis table 8 maka dapat dirumuskan persamaan sebagai berikut:

$$
\mathrm{JPM}=28494,382 \text { - 215,553 PE }
$$

Dari persamaan tabel 8 dapat dijelaskan sebagai berikut diketahui nilai thitung bernilai negatif sebesar 0,591 sedangkan $t_{\text {tabel }}$ pada $\mathrm{dk}=\mathrm{n}-1=11$, yaitu sebesar 2,201. Dengan demikian $t_{\text {hitung }}<\mathrm{t}_{\text {tabel }}$, begitupun signifikansi sebesar 0,602 yang lebih besar dari taraf signifikansi $(\alpha)=0,05$. Hal ini berarti bahwa $\mathrm{H}_{\mathrm{o}}$ diterima $\mathrm{H}_{\mathrm{a}}$ ditolak. Dengan demikian pertumbuhan ekonomi tidak memiliki pengaruh yang signifikan terhadap perkembangan jumlah penduduk miskin.

Selanjutnya, pengaruh pertumbuhan ekonomi terhadap persentase penduduk miskin di Kabupaten Tanjung Jabung Timur tahun 2004-2015. Hasil analisis pengaruh pertumbuhan ekonomi terhadap persentase penduduk miskin di Kabupaten Tanjung Jabung Timur tahun 2004-2015 dapat dilihat pada tabel 9 berikut:

Tabel 9. Hasil analisis pengaruh pertumbuhan ekonomi terhadap persentase penduduk miskin di Kabupaten Tanjung Jabung Timur tahun 2004-2015

\begin{tabular}{lcrr}
\hline \multicolumn{1}{c}{ Variabel } & Koefisien & \multicolumn{1}{c}{ thitung $_{\text {r }}$} & Signifikansi \\
\hline Constant & 13,708 & 15,758 & 0,000 \\
$\mathrm{PE}$ & $-0,154$ & $-0,926$ & 0,376 \\
$\mathrm{t}_{\text {tabel }}=1,812$ & & & \\
\hline
\end{tabular}

Sumber: Data diolah, 2017

Berdasarkan hasil analisis tabel 9 di atas maka dapat dirumuskan persamaan sebagai berikut:

\section{$P P M=13,708-0,154$ PE}

Dari tabel 9 diketahui nilai $t_{\text {hitung }}$ bernilai negatif sebesar 0,926 sedangkan $t_{\text {tabel }}$ pada $\mathrm{dk}=\mathrm{n}-1=11$, yaitu sebesar 2,201. Dengan demikian $\mathrm{t}_{\text {hitung }}<\mathrm{t}_{\text {tabel }}$, begitupun signifikansi sebesar 0,376 yang lebih besar dari taraf signifikansi $(\alpha)=0,05$. Hal ini berarti bahwa $\mathrm{H}_{\mathrm{o}}$ 
diterima $\mathrm{H}_{\mathrm{a}}$ ditolak. Dengan demikian, pertumbuhan ekonomi tidak memiliki pengaruh yang signifikan terhadap perkembangan persentase penduduk miskin.

\section{Pengaruh pertumbuhan ekonomi terhadap kedalaman kemiskinan di Kabupaten Tanjung Jabung Timur tahun 2004-2015}

Hasil analisis pengaruh pertumbuhan ekonomi terhadap kedalaman kemiskinan di Kabupaten Tanjung Jabung Timur tahun 2004-2015 dapat dilihat pada tabel berikut:

Tabel 10. Hasil analisis pengaruh pertumbuhan ekonomi terhadap kedalaman kemiskinan di Kabupaten Tanjung Jabung Timur tahun 2004-2015

\begin{tabular}{lcrr}
\hline \multicolumn{1}{c}{ Variabel } & Koefisien & thitung & Signifikansi \\
\hline Constant & 2,450 & 6,341 & 0,000 \\
$\mathrm{PE}$ & $-0,094$ & $-1,273$ & 0,232 \\
$\mathrm{t}_{\text {tabel }}=1,812$ & & & \\
\hline
\end{tabular}

Sumber: Data diolah, 2017

Berdasarkan hasil analisis tabel 10 maka dapat dirumuskan persamaan sebagai berikut:

$\mathrm{KdK}=2,450-0,094 \mathrm{PE}$

Dari tabel 10 dapat dijelaskan sebagai beridiketahui nilai thitung bernilai negatif sebesar 1,273 sedangkan $t_{\text {tabel }}$ pada $\mathrm{dk}=\mathrm{n}-1=11$, yaitu sebesar 2,201. Dengan demikian $t_{\text {hitung }}<t_{\text {tabel }}$, begitupun signifikansi sebesar 0,232 yang lebih besar dari taraf signifikansi $(\alpha)=0,05$. Hal ini berarti bahwa $\mathrm{H}_{\mathrm{o}}$ diterima $\mathrm{H}_{\mathrm{a}}$ ditolak. Dengan demikian, pertumbuhan ekonomi tidak memiliki pengaruh yang signifikan terhadap indeks kedalaman.

\section{Pengaruh pertumbuhan ekonomi terhadap keparahan kemiskinan di Kabupaten Tanjung Jabung Timur tahun 2004-2015}

Hasil analisis pengaruh pertumbuhan ekonomi terhadap keparahan kemiskinan di Kabupaten Tanjung Jabung Timur tahun 2004-2015 dapat dilihat pada tabel berikut:

Tabel 11. Hasil analisis pengaruh pertumbuhan ekonomi terhadap keparahan kemiskinan di Kabupaten Tanjung Jabung Timur tahun 2004-2015

\begin{tabular}{lcrr}
\hline \multicolumn{1}{c}{ Variabel } & Koefisien & thitung & Signifikansi \\
\hline Nilai konstan $(\alpha)$ & 0,635 & 4,262 & 0,002 \\
PE & $-0,030$ & $-1,069$ & 0,310 \\
$\mathrm{t}_{\text {tabel }}=1,812$ & & &
\end{tabular}

Sumber: Data diolah, 2017

Berdasarkan hasil analisis tabel 11 maka dapat dirumuskan persamaan sebagai berikut:

$$
\text { KpK = 0,635 - 0,030 PE }
$$

Dari tabel 11 dapat diketahui nilai thitung bernilai negatif sebesar 1,069 sedangkan $\mathrm{t}_{\text {tabel }}$ pada $\mathrm{dk}=\mathrm{n}-1=11$, yaitu sebesar 2,201. Dengan demikian $\mathrm{t}_{\text {hitung }}<\mathrm{t}_{\text {tabel }}$, begitupun signifikansi sebesar 0,310 yang lebih besar dari taraf signifikansi $(\alpha)=0,05$. Hal ini berarti bahwa $\mathrm{H}_{\mathrm{o}}$ diterima $\mathrm{H}_{\mathrm{a}}$ ditolak. Dengan demikian, pertumbuhan ekonomi tidak memiliki pengaruh yang signifikan terhadap indeks keparahan kemiskinan.

\section{KESIMPULAN DAN SARAN}

\section{Kesimpulan}

Berdasarkan hasil penelitian dan pembahasan, maka dapat disimpulkan bahwa pertumbuhan ekonomi tidak mempengaruhi kemiskinan di Kabupaten Tanjung Jabung Timur tahun 2004-2015. Hal ini bisa dilihat dari hasil pengujian hipotesis yang 
menunjukkan bahwa pertumbuhan ekonomi tidak memiliki pengaruh yang signifikan terhadap garis kemiskinan. Begitupun dengan pengaruh pertumbuhan ekonomi terhadap jumlah penduduk miskin, persentase penduduk miskin, indeks kedalaman kemiskinan dan indeks keparahan kemiskinan yang menunjukkan tidak adanya pengaruh yang signifikan.

\section{Saran}

Pertumbuhan ekonomi dan kemiskinan merupakan indikator keberhasilan pembangunan ekonomi. Oleh karena itu, maka diharapkan Pemerintah Kabupaten Tanjung Jabung Timur agar dapat terus mengevaluasi kebijakan pembangunan ekonomi terutama yang diarahkan pada peningkatan taraf hidup penduduk miskin demi pengentasan kemiskinan di Kabupaten Tanjung Jabung Timur. Bagi peneliti lain supaya melakukan penelitian menggunakan faktor-faktor lain seperti kebijakan pembangunan infrastruktur, pendapatan asli daerah, alokasi belanja daerah dan lain sebagainya.

\section{DAFTAR PUSTAKA}

Arifin, Bustanul Didik J. Rachbini. (2001). Ekonomi politik dan kebijakan publik, Gramedia: Jakarta

Arikunto, S. (2000). Manajemen penelitian. Rineka Cipta: Jakarta.

Ghozali, Imam.(2006).Aplikasi analisis multivariat dengan program SPSS. Badan Penerbitan Universitas Diponegoro: Semarang.

Gilarso (1991) Pengantar ilmu ekonomi makro. Kanisius: Yogyakarta

Gujarati, Damodar. (2006). Dasar-dasar ekonometrika, Erlangga: Jakarta

H Harlik, A Amir, H Hardiani. (2013).Faktor-faktor yang mempengaruhi kemiskinan dan pengangguran di Kota Jambi,Jurnal Perspektif Pembiayaan dan Pembangunan Daerah 1 (2), 109-120

Harlik, Amri. Amir, Hardiani. (2013). Faktor-faktor mempengaruhi kemiskinan dan pengangguran di Kota Jambi. Jurnal perspektif pembiayaan dan pembangunan daerah. 1(2), 109-120

Jhingan, M.L. (2000). Ekonomi pembangunan dan perencanaan, Raja Grafindo Persada: Jakarta

Khusaini, Mohammad. (2006). Ekonomi publik - desentralisasi fiskal dan pembangunan daerah, BPFE Unibraw: Malang.

Mayati Anis, Syaparuddin. Erni, Achmad. (2013). Analisis PDRB sektor primer dan kesempatan kerja di Kabupaten Bungo. Jurnal perspektif pembiayaan dan pembangunan daerah. 1(1), 51-62

NF Alin, H Heriberta, E Umiyati. (2019).Fakta empiris kurva U-terbalik Kuznets mengenai pertumbuhan ekonomi di Provinsi Jambi, Jurnal Paradigma Ekonomika 14 (1), 9-16 